\title{
Aquatic vascular plants as handicraft: a case study in southern Brazil
}

\author{
Mabel R. Báez-Lizarazo ${ }^{1^{*}}$, Flavia Rosa Santoro², Ulysses Paulino Albuquerque ${ }^{2}$ and Mara Rejane Ritter ${ }^{1}$
}

Received: August 1, 2017

Accepted: September 18, 2017

\begin{abstract}
This study aimed to evaluate knowledge about and the usage and importance of aquatic vascular plants (AVPs) in the production of handicrafts by communities on the north coast of the state of Rio Grande do Sul in southern Brazil. The snowball technique was employed to locate people who use and have knowledge regarding the use of AVPs for handicrafts. Data were collected through semi-structured interviews and guided tours with 35 interviewees who were involved in artisanal activity at the time of the study. The data were analyzed using the importance value (IV) index and the consensus value for the forms of use (CMU). The Spearman correlation test (rs) was employed to determine the correlations of each social variable with the knowledge variables, and Mann-Whitney U tests to verify whether men and women exhibited differences in knowledge. The interviewees cited 16 AVPs that were employed in 17 types of handicrafts, among which the four main species were Schoenoplectus californicus, Typha domingensis, T. latifolia and Androtrichum giganteum. Interviewee age, residence time on site and time working with handicrafts were the main social parameters that described the level of knowledge and use of AVPs. These AVPs reflect cultural knowledge and complement family incomes.
\end{abstract}

Keywords: aquatic macrophytes, ethnobotany, craft, non-timber plant products, Schoenoplectus californicus, Typha

\section{Introduction}

Crafting is an important source of income and employment for local populations and provides a manner through which culture can reaffirm itself (Marcus 2000; Alexiades \& Shanley 2004). In this context, aquatic vascular plants (AVPs) can represent a fundamental resource for the livelihoods of many communities in different locations worldwide, especially because of their use in the production of handicrafts (Heiser 1978; Macía \& Balslev 2000; Rondón et al. 2003; Vidaurre et al. 2006; Dogan et al. 2008). Handicrafts are widely mentioned in studies that focus on the use of forest species (Guadagnin \& Gravato 2013), whereas little is known about the use of
AVPs for this purpose. For example, the identification of the forest species used for handicrafts and their forms of use, along with characterization of the knowledge of people who use these species, has allowed the impact on species and vegetal communities in Africa and Europe to be evaluated, as well as the cultural and economic value of these species (Cunningham 2001; Barber \& Krivoshlykova 2006). Additionally, it is important to determine which species are the most culturally important, as the focused importance of some species can lead to high handicraft specialization, resulting in the over-exploitation of some species (Contreras 1982). Knowledge of the versatility of a resource is also essential to determine the degree of susceptibility to over-exploitation (Jain et al. 2005; Kotze \& Traynor 2011).

1 Programa de Pós-Graduação em Botânica, Laboratório de Taxonomia de Angiospermas, Universidade Federal do Rio Grande do Sul, Campus do Vale, 91501-970, Porto Alegre, RS, Brazil

2 Laboratório de Ecologia e Evolução dos Sistemas Sócio-Ecológicos, Departamento de Botânica, Universidade Rural Federal de Pernambuco, Dois Irmãos, 52171-900, Recife, PE, Brazil

*Corresponding author: mabel.baez@ufrgs.br, mabelrbl@gmail.com 
Associated with the above aspects, the acquisition of reliable social data that indicate who is involved in the use and knowledge of plants, as cited in Gavin \& Anderson (2007), is fundamental in the search for strategies that involve communities in effective management plans adjusted to the local context and contribute to the conservation of natural resources (Sunderland \& Ndoye 2004). In the literature, it is generally suggested that local knowledge, residence time on site (Gavin \& Anderson 2007), gender (CamouGuerrero et al. 2008; Torres-Avilez et al. 2014; Torri 2014) education and age (Martin 1995; Gavin \& Anderson 2007) are predictors of the use of cultural species for medicine, building and handicraft.

The purpose of this study is to identify the knowledge, actual use, importance and versatility of AVPs employed in artisanal activities by communities on the North Coast of Rio Grande do Sul, southern Brazil. Additionally, this work aims to describe the forms of plant extraction and artisanal production and to characterize people who use AVPs for handicraft. Supported by the literature, the hypothesis of this study is that social factors, such as gender, age, residence time and time working with handicraft, are related to the knowledge and use of these plants.

\section{Materials and methods}

\section{Study area}

The southern region of Brazil is rich in wetlands (Junk et al. 2014). Specifically, the northern coast of Rio Grande do Sul, Brazil (Fig. 1), includes $120 \mathrm{~km}$ of beach encompassing 16 coastal lagoons, which are affected by social and environmental conflicts (Coelho-de-Souza et al. 2008). The effects of these conflicts on plant use and extraction are an important issue in the conservation and sustainable management of natural resources (Arruda 1999). This area is located in the subtropical region of America, specifically in the Atlantic forest, and is characterized by intense urbanization and high seasonal variation in the human population.

This study focused exclusively on wetlands in the municipalities of Imbé, Osório, and Maquiné, where there are people who currently work in the process of elaboration of handicrafts. Historically, these activities have been practiced in the region for over 50 years. These municipalities are part of the Tramandaí River Basin and are strongly influenced by wetlands, such as swamps, rivers, and lagoons, and they are considered permanent preservation areas (PPAs) (Brasil 2012).

In the municipality of Osório (44.190 inhabitants), there is a wind farm representing a key economic factor; in the municipality of Imbé (20.294), there are beaches that receive thousands of tourists, which influence the economy; and the municipality of Maquiné (7.028), a mainly rural area, depends on agriculture and eco-tourism (IBGE 2016).

\section{Legal and ethical aspects}

All participants were asked to sign the Terms of Free and Informed Consent (TFIC), authorizing the collection, use, and publication of data obtained in this study (Term S1 in Supplementary material). Moreover, this study was approved by the Ethics Committee on Research of the Federal University of Rio Grande do Sul, registered under $\mathrm{n}^{\circ}$ 384.902, with Certificate of Presentation to Ethical Appreciation (CPEA) n 19521913.6.0000.5347.

\section{Data collection}

Data collection was performed from October 2013 to November 2014. The population using AVPs for handicrafts (including people with a relationship to the handicraft process) was located through the snowball method (Bailey 1994), starting with key informants who were located based on studies that were previously performed in the region (Silveira et al. 2007; 2011a; b; Coelho-de-Souza et al. 2008).

A total of 21 subjects were located in the municipality of Osório, 12 in the municipality of Maquiné, and two in the municipality of Imbé. Using semi-structured interviews and forms (Albuquerque et al. 2014), we characterized and registered social data, such as age, occupation, sex, education, residence time and experience time with handicraft, in a survey. The sort of activity that was performed within artisanal practices (collecting and/or plant weaving), the names of the plants that were known and/or used, and the type of handicraft that was made from each species were also verified. A guided-tour technique (Albuquerque et al. 2014) was employed for the localization and characterization of collection areas, identification, and plant extraction, as well as the processing of raw material (Correa et al. 2010). Moreover, each person was followed during the process of craft-making to identify the handicraft items that were made.

Among the 35 interviewees, the average age was 39 $( \pm 19)$ years, with a minimum of 11 years and a maximum of 77 years. The 17 women among the subjects exhibited an average age of $50( \pm 16)$ years, and the 18 men exhibited an average age of $29( \pm 16.5)$ years. According to the activities performed in the production of handicrafts, the interviewees were divided into 15 cutters of raw material and 20 individuals who made handicrafts, with eight people working in both activities. The main income sources declared were temporary jobs (31\%), retirement (23\%), agriculture (14\%), handicraft (14\%), fishing (9\%) and carpentry (9\%). A total of $86 \%$ of the interviewees declared handicrafts to be a secondary income source, among whom $20 \%$ were active artisans registered in the Fundação Gaúcha do Trabalho e Ação Social (FGTAS, 2016).

The collected plants were identified and deposited at the Herbarium of the Bioscience Institute (ICN herbariumUFRGS) with the voucher labels Báez-L.M.R. 151 to 204. 


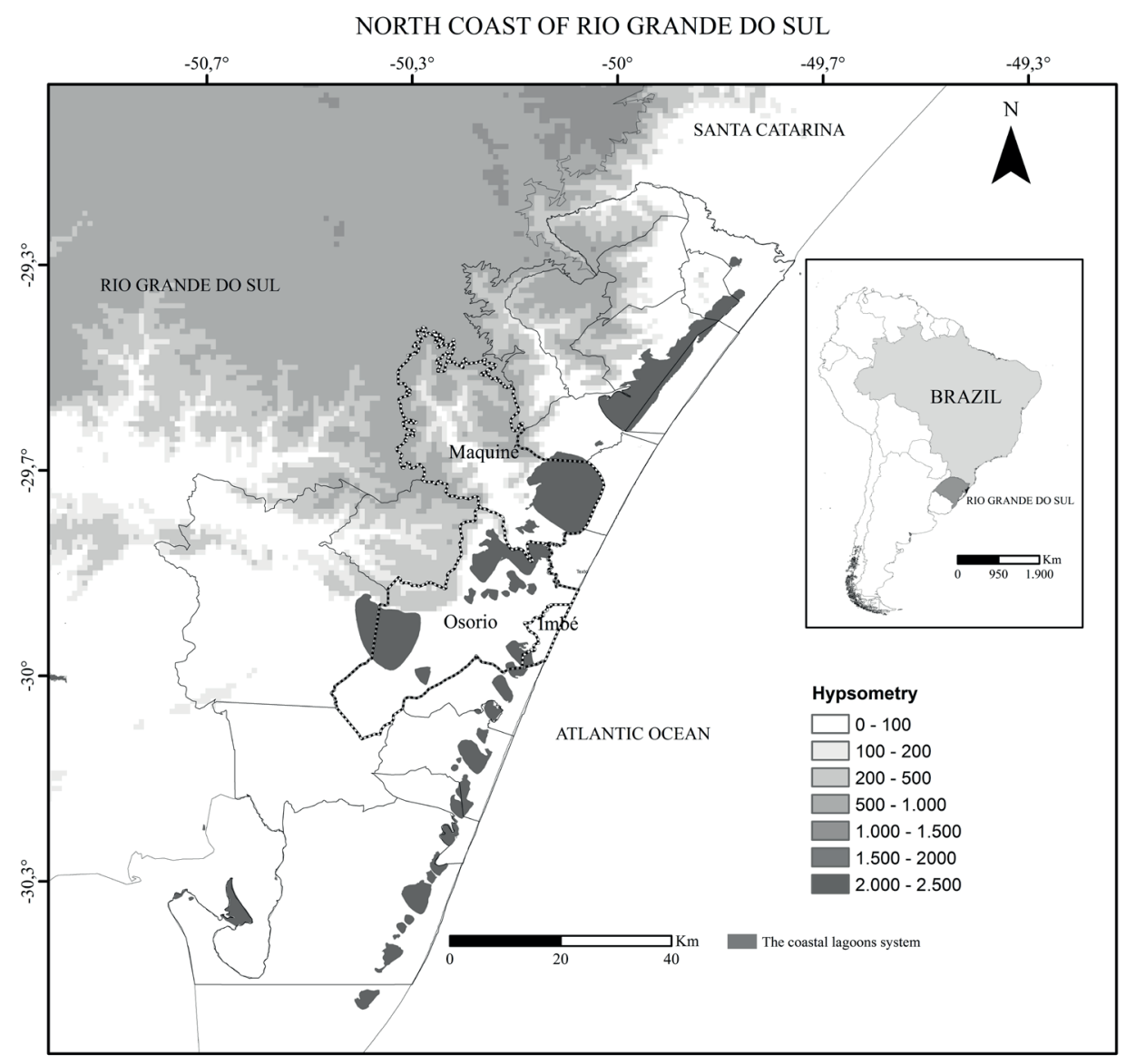

Figure. 1 Geographical location of the study area, North Coast of Rio Grande do Sul, Brazil. The map was produced with the software Arcgis 10.3.

Classification at the family level was performed using the APG IV system (Stevens 2016). The names of the plants recorded in this study were updated according to data from The Plant List database (www.theplantlist.org). The plants that were mentioned by interviewees as occurring in wetlands were classified as aquatic based on Irgang \& Gastal (1996), Rolon et al. (2010), and Alves et al. (2015). Additionally, the Endangered Species List of Species of Flora of Brazil (Alves et al. 2015) was consulted to note the state of threat as well as the origin and distribution of certain species.

\section{Data analysis}

Social data and the number of identified AVPs were analyzed qualitatively and quantitatively. Emic classification was chosen for those analysis reflecting local knowledge (Arruda 1999), revealing a diversity distinct from the diversity obtained through scientific classification; for example, the plant referred to as "taboa" was identified as both Typha domingensis and T. latifolia, but the analysis considered these as one plant because interviewees did not differentiate them. In contrast, the Species with the popular name "tiririca" were not grouped as a single species in this analysis because each plant was differentiated by the interviewees, who recognized them as similar according to the shape of their leaves but differentiated them according to plant size and the shape of the inflorescences.

To quantify the knowledge and use of aquatic plants for handicrafts, we employed the following three parameters: the number of known plants, the number of plants used for handicrafts and the number of handicraft items that were made using each plant. The last variable represents binomial plant use (for example, "junco"-mat, "junco"-hat) and was chosen because the number of plants and the number of uses assigned to each plant were quantified in one unit, showing a more detailed aspect of the knowledge of AVPs for handicrafts. For example, one person may use "junco" only to make a mat, while another with greater knowledge uses it to make mats, hats and chairs. This binomial variable was termed the information unit (IU), following the designation of Santoro et al. (2015), who employed the same strategy in their study on medicinal plants.

The index of importance values (IVs) (Byg \& Balslev 2001) was used to identify the most important species, and the index of consensus value for the forms of use (CMU=Mx/ $\mathrm{Mt}$ ) (Monteiro et al. 2006), which is the number of citations for a given form of use $(\mathrm{Mx})$ divided by the total number of 
citations for all forms (Mt). CMU was employed to identify the versatility of used species. For CMU, the total number of different forms of use (or information unit) was initially obtained for all plants. Moreover, using this list of shapes, we obtained CMU for each IU pertaining to each AVP (Tab. 1). In this analysis, the form of handicraft referred to as braids (vegetal fibers entwined with each other), from which other artisanal works such as bags, pan holders, and fans are made, was considered independently because some people only weaved.

To determine whether social variables were associated with the knowledge and use of aquatic plants employed for handicrafts, correlations were performed between the variables age, education, residence time on site, working time with handicrafts, number of known species, number of used species and number of IUs. To determine whether there was a relationship between what one knows, uses and/or manufactures, we calculated correlations using the number of known plants, the number of used plants and IUs. The Spearman correlation test (rs) was employed to correlate each social variable with the knowledge variables and between-knowledge variables. To verify whether men and women had knowledge of different AVPs, we used MannWhitney $\mathrm{U}$ tests to compare the number of known plants,

Table 1. List of species of aquatic vascular plants that are used for handicrafts and the consensus values for the forms of use (CMU) in southern Brazil.

\begin{tabular}{|c|c|c|c|c|c|}
\hline Family / scientific name & Popular name & Used part & Information unit (IU) & CMU & $\mathrm{N}^{\circ}$ of citations \\
\hline \multicolumn{6}{|l|}{ Cyperaceae } \\
\hline Androtrichum giganteum (Kunth) H. Pfeiff. & Tiririca & Leaves & $\begin{array}{l}\text { Braids } \\
\text { Bags } \\
\text { Hats } \\
\text { Table ornaments } \\
\text { Rugs } \\
\text { Fans } \\
\text { Mats }\end{array}$ & $\begin{array}{c}\mathbf{0 . 1 0 9}^{*} \\
0.047 \\
0.047 \\
0.063 \\
0.031 \\
0.031 \\
0.344\end{array}$ & 6 \\
\hline Cyperus eragrostis Lam. & Tiririca & Inflorescence & Arrangements & 0.016 & 1 \\
\hline Cyperus hermaphroditus (Jacq.) Standl. & Tiririca & Inflorescence & Arrangements & 0.016 & 1 \\
\hline Cyperus odoratus L. & Tiririca & Inflorescence & Arrangements & 0.016 & 1 \\
\hline Cyperus prolixus Kunth & Tiririca & Inflorescence & Arrangements & 0.016 & 1 \\
\hline Cyperus rigens J. Presl \& C. Presl & Tiririca & Inflorescence & Arrangements & 0.016 & 1 \\
\hline Cyperus surinamensis Rottb. & Tiririca & Inflorescence & Arrangements & 0.016 & 1 \\
\hline Eleocharis montana (Kunth) Roem. \& Schult. & Tiririca & Inflorescence & Arrangements & 0.016 & 1 \\
\hline Fimbristylis dichotoma (L.) Vahl & Tiririca & Inflorescence & Arrangements & 0.016 & 1 \\
\hline Kyllinga odorata Vahl & Sempre-viva & Inflorescence & Arrangements & 0.016 & 1 \\
\hline Rhynchospora holoschoenoides (Rich.) Herter & Tiririca & Inflorescence & Arrangements & 0.016 & 1 \\
\hline Schoenoplectus californicus (C.A.Mey.) Soják & $\begin{array}{l}\text { Junco-redondo, } \\
\text { Junco-três-quinas } \\
\text { or Piri }\end{array}$ & Secondary stem & $\begin{array}{c}\text { Mats, "esteiras" } \\
\text { Decorative table setting } \\
\text { Table ornaments } \\
\text { Pan keepers }\end{array}$ & $\begin{array}{c}\mathbf{0 . 3 4 4}^{*} \\
0.047 \\
0.063 \\
0.031\end{array}$ & 23 \\
\hline \multicolumn{6}{|l|}{ Juncaceae } \\
\hline Juncus microcephalus Kunth & Junquinho & Inflorescence & Arrangements & 0.016 & 1 \\
\hline Poaceae & & & & & \\
\hline Andropogon bicornis L. & Rabo-de-burro & Inflorescence & Arrangements & 0.016 & 1 \\
\hline Typhaceae & & & & & \\
\hline $\begin{array}{l}\text { Typha domingensis Pers. } \\
\text { Typha latifolia L. }\end{array}$ & Taboa & Leaves & $\begin{array}{c}\text { Chair, "empalhamento" } \\
\text { Braids } \\
\text { Trays } \\
\text { Gourd keepers } \\
\text { Cachepots } \\
\text { Bags } \\
\text { Boxes } \\
\text { Hats } \\
\text { Table ornaments } \\
\text { Fruit bowls } \\
\text { Fans } \\
\text { Pan keepers } \\
\text { Rugs }\end{array}$ & $\begin{array}{c}\mathbf{0 . 0 9 4}^{*} \\
\mathbf{0 . 1 0 9}^{*} \\
0.031 \\
0.031 \\
0.016 \\
0.047 \\
0.016 \\
0.047 \\
0.063 \\
0.031 \\
0.031 \\
0.031 \\
0.031\end{array}$ & 14 \\
\hline
\end{tabular}


used plants and IUs. Additionally the chi-square test $\left(X^{2}\right)$ was employed to compare the division of activity associated with cutters, weavers and cutter-weavers between men and women. The results were analyzed with and without outliers (extreme values) (see Araújo et al. 2012) by first applying the Shapiro-Wilk test for normality and then determining the quartile $\left(Q_{1}\right)$ to obtain extreme values for used plants, known plants and IUs. The Shapiro-Wilk test of normality resulted in $\mathrm{p}=0.0001$ for data on known plants, used plants and IUs. An extreme value for both used plants and known plants was subsequently obtained, along with 10 extreme values for IUs (which considers a plant and its respective use). One interviewee who was considered an outlier mentioned 12 species of AVPs with artisanal uses.

The means and standard deviations were the descriptive statistics employed to obtain the average population age as well as the known plants, used plants and IUs to determine the degree of dispersion of knowledge between men and women. The InfStat 2008 (Rienzo et al. 2017) statistical program was employed for all statistical analyses in this study.

\section{Results}

\section{Knowledge of aquatic vascular plants that are used for handicrafts}

A total of 16 currently used AVPs species were registered, belonging to 10 genera from four botanical families. The Cyperaceae family, with 12 species, was the most species-rich family recorded, followed by Typhaceae, with two species; and Poaceae and Juncaceae, with one species each (Tab. 1).

All of the species were native to Brazil, but the only endemic species was Fimbristylis dichotoma (Alves et al. 2015), known as "tiririca", which is used for arrangements. The parts of the plants that were most commonly used and collected by artisans were the ramifications of secondary stems $(65.7 \%)$ and leaves (57.1\%). Inflorescences were used by a single interviewee. Among the 16 species, four were the most important to the community, with Schoenoplectus californicus exhibiting the highest importance according to its IV (IV=0.66), followed by Typha domingensis and T. latifolia (both IVs=0.40) and Androtrichum giganteum $(I V=0.17)$. Another 12 species each presented an IV=0.02 because they were mentioned by a single person.

\section{Versatility of aquatic vascular plants for handicrafts}

A total of 17 forms of use were cited for the 16 species of AVPs ( $n=20$ people) (Fig. 2), which were determined from the consensus values for the form of use (CMU), highlighting mats $(C M U=0.344)$, braids $(C M U=0.109)$ and fiber for covering chairs (CMU=0.094) (Table 1$)$. Mats were used in multiple ways, ranging from material for family use to decorative and even building material (coverage for roofs of kiosks and tents).

The CMU data for the four species with the highest IVs are presented in Table 3. The main use for "junco" (Schoenoplectus californicus) was the production of mats ( $C M U=0.8, \mathrm{n}=21$ ), while that for "taboa" (Typha domingensis and T. latifolia) was covering chairs (CMU=0.22, n=9), and that for "tiririca" Androtrichum giganteum was braiding $(\mathrm{CMU}=0.39, \mathrm{n}=5)$. Various artisanal objects were produced (Tab. 2); the most commonly used plant was "junco", and the species exhibiting the greatest number of artisanal types was "taboa", with a total of 13 forms of use. Only interviewees with a degree of kinship used Androtrichum giganteum.

\section{Social variables related to the knowledge and artisanal use of aquatic vascular plants}

Table 3 shows the correlation results for social data associated with known plants, used plants and IUs. The correlation results for certain categories (e.g., known plants and used plants), either with or without outliers, indicated no correlation with education. When IUs with a zero (0) value (i.e., exclusively cutting of the raw material) and the outliers $(n=19)$ were excluded, no correlation with education or time on site was detectable.

The comparison of knowledge between men and women using the Mann-Whitney U test yielded significant differences for the IUs $(\mathrm{p}=0.0019 ; \mathrm{n}=35)$, indicating that women produced more handicrafts than men. There was no difference between men and women with respect to the number of known plants $(\mathrm{p}=0.29 ; \mathrm{n}=35)$ and used plants $(\mathrm{p}=0.30 ; \mathrm{n}=35)$. The mean values and standard deviations obtained for men (18) and women (17) pertaining to known plants were $3.24 \pm 3.44$ and $1.94 \pm 0.80$; those for used plants were $2.06 \pm 3.13$ and $1.11 \pm 0.32$; and those for IUs were $3.76 \pm 5.18$ and $0.83 \pm 1.15$, respectively. In contrast, the results of $X^{2}=8.77, \mathrm{p}<0.05$ obtained between cutters $(\mathrm{n}=7)$, weavers (20) and cutters-weavers (8) indicated that gender is related to craft activities, with women being more closely associated with weaving and men with cutting.

\section{Methods for collecting of AVPs and the production of artisanal items}

The Methods for collecting of AVPs included the following activities: 1 ) selection of the area and plants to cut, 2) cutting of plants, 3) drying of collected plants and 4) production of handicraft items. The 16 species were collected in different areas, such as permanent and seasonal wetlands, lagoons, abandoned weirs, and wetlands bordering roads. The collection points were influenced by the time since the last plants were collected ( $45 \%$ ), environmental conditions (45\%), the features and quality of the raw materials (37 $\%)$, the accessibility of locations ( $28 \%$ ) and, the need for 

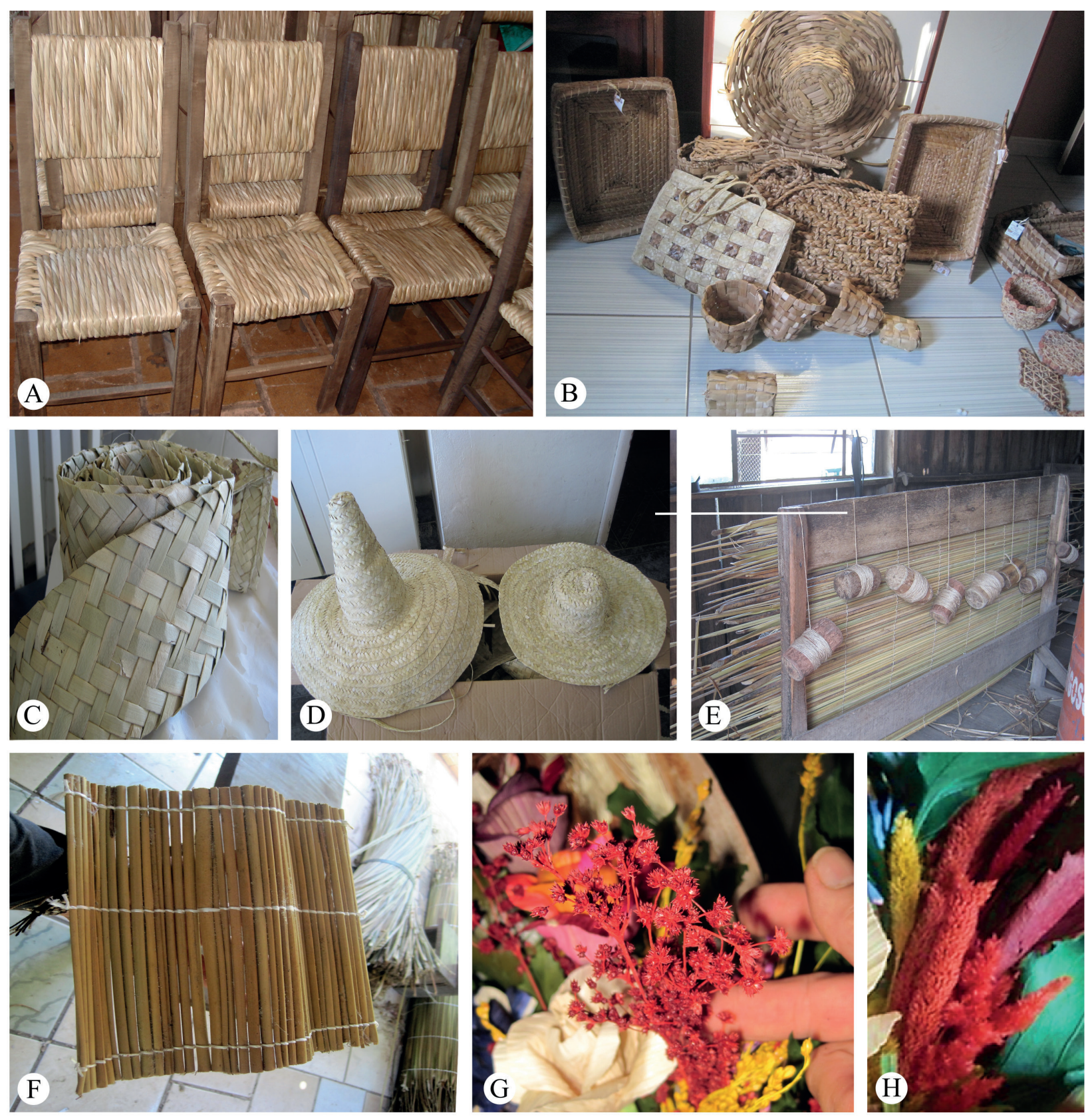

Figure 2. Forms of use of different species of aquatic vascular plants: "taboa": A - Chair "empalhamento", B - Different handicrafts. "tiriricas", C - braids, D - hats. "junco", E - mat on the "cavalete", F - decorative table setting. "capins", G and H - arrangements of inflorescences.

raw materials (8\%). There was no record of cultivation of any of the used species. Residents of Osório, who worked mainly with Schoenoplectus californicus, performed collection in lagoons. In the municipalities of Imbé and Maquiné, collections were performed in wetlands.

Species were selected based on morphological features that were considered optimal for artisanal work. In the case of "junco" (Schoenoplectus californicus), plants were mainly selected when they exhibited stems with a larger diameter, were firm and green, and the stem presented a rounded shape ( $100 \%, 86 \%, 82 \%$ and $73 \%$, respectively). In the case of "taboa" (Typha domingensis and T. latifolia), the preference was for plants without inflorescence, with long and strong leaves, and for adult plants (mature) with numerous leaves ( $100 \%, 85 \%, 71 \%$, and $57 \%$, respectively). All other "tiriricas" and "capins" were selected based on inflorescence density.

The cutters waited at least five to six months to cut species such as "taboa" (Typha domingensis and T. latifolia), "tiririca" (Androtrichum giganteum) and "junco" 
Table 2. Forms of use of aquatic vascular plants with the highest importance values. CMU: consensus value for the forms of use.

\begin{tabular}{|c|c|c|}
\hline Scientific name & Products & CMU \\
\hline \multirow{4}{*}{$\begin{array}{l}\text { Schoenoplectus californicus - "Junco" } \\
\qquad\left(\mathrm{n}_{\text {people }}=18\right)\end{array}$} & Mats, "esteiras" & $0.80^{*}$ \\
\hline & Decorative table setting & 0.11 \\
\hline & Table ornaments & 0.04 \\
\hline & Pan keepers & 0.04 \\
\hline \multirow{13}{*}{$\begin{array}{l}\text { Typha domingensis, T. latifolia - "Taboa" } \\
\qquad\left(\mathrm{n}_{\text {people }}=14\right)\end{array}$} & Chair covering, "empalhamento" & $0.22 *$ \\
\hline & Braids & 0.11 \\
\hline & Trays & 0.07 \\
\hline & Gourd keepers & 0.07 \\
\hline & Cachepots & 0.04 \\
\hline & Bags & 0.07 \\
\hline & Boxes & 0.07 \\
\hline & Hats & 0.07 \\
\hline & Table ornaments & 0.07 \\
\hline & Fruit bowls & 0.07 \\
\hline & Fans & 0.04 \\
\hline & Pan keepers & 0.04 \\
\hline & Rugs & 0.04 \\
\hline \multirow{7}{*}{$\begin{array}{l}\text { Androtrichum giganteum - "Tiririca" } \\
\qquad\left(\mathrm{n}_{\text {people }}=5\right)\end{array}$} & Braids & $0.39 *$ \\
\hline & Bags & 0.18 \\
\hline & Hats & 0.09 \\
\hline & Table ornaments & 0.09 \\
\hline & Rugs & 0.09 \\
\hline & Fans & 0.09 \\
\hline & Mats, "esteiras" & 0.09 \\
\hline
\end{tabular}

*Significant data for the most important AVPs with CMUs

Table 3. Spearman correlation (rs) for known aquatic vascular plants (AVPs), used AVPs, information units and data with outliers $(n=35)$ and without outliers. An informant who was considered an outlier mentioned 12 species of AVPs with artisanal uses.

\begin{tabular}{|c|c|c|c|c|c|c|}
\hline Plant data / social data & Known plants & Used plants & Age & Time on site & Time working with VAPs & Education \\
\hline $\begin{array}{c}\text { Known plants } \\
\mathrm{n}=35\end{array}$ & 1 & $\begin{array}{l}\mathrm{rs}=0.63^{*} \\
\mathrm{p}=0.0001\end{array}$ & $\begin{array}{l}r s=0.64^{*} \\
p=0.0001\end{array}$ & $\begin{array}{c}r s=0.41 \\
p=0.0147\end{array}$ & $\begin{array}{l}\mathrm{rs}=0.66^{*} \\
\mathrm{p}=0.0001\end{array}$ & $\begin{array}{l}\mathrm{rs}=-0.3 \\
\mathrm{p}=0.08\end{array}$ \\
\hline $\begin{array}{l}\text { Known plants } \\
\text { without outliers } n=34\end{array}$ & 1 & $\begin{array}{c}r s=0.58 \\
p=0.0004\end{array}$ & $\begin{array}{l}\mathrm{rs}=0.54 \\
\mathrm{p}=0.001\end{array}$ & $\begin{array}{l}\mathrm{rs}=0.54 \\
\mathrm{p}=0.001\end{array}$ & $\begin{array}{l}\mathrm{rs}=0.66^{*} \\
\mathrm{p}=0.001\end{array}$ & $\begin{array}{l}r s=-0.24 \\
p=0.169\end{array}$ \\
\hline $\begin{array}{l}\text { Used plants } \\
\mathrm{n}=35\end{array}$ & $\begin{array}{l}\mathrm{rs}=0.63^{*} \\
\mathrm{p}=0.0001\end{array}$ & 1 & $\begin{array}{c}\mathrm{rs}=0.48 \\
\mathrm{p}=0.0036\end{array}$ & $\begin{array}{c}r s=0.35 \\
p=0.0377\end{array}$ & $\begin{array}{c}\mathrm{rs}=0.5 \\
\mathrm{p}=0.0024\end{array}$ & $r s=-0.18 p=0.299$ \\
\hline $\begin{array}{l}\text { Used plants } \\
\text { without outliers } n=34\end{array}$ & $\begin{array}{c}\mathrm{rs}=0.58 \\
\mathrm{p}=0.0004\end{array}$ & 1 & $\begin{array}{c}r s=0.47 \\
p=0.0048\end{array}$ & $\begin{array}{l}r s=0.54 \\
p=0.001\end{array}$ & $\begin{array}{c}r s=0.44 \\
p=0.0036\end{array}$ & $\begin{array}{l}r s=-0.09 \\
p=0.6175\end{array}$ \\
\hline $\begin{array}{c}\text { Information units } \\
\mathrm{n}=35\end{array}$ & $\begin{array}{c}r s=0.45 \\
p=0.00065\end{array}$ & $\begin{array}{c}r s=0.52 \\
p=0.0014\end{array}$ & $\begin{array}{c}r s=0.42 \\
p=0.0115\end{array}$ & $\begin{array}{l}r s=0.21 \\
p=0.222\end{array}$ & $\begin{array}{l}\mathrm{rs}=0.44 \\
\mathrm{p}=0.085\end{array}$ & $\begin{array}{c}r s=-0.4 \\
p=0.0172\end{array}$ \\
\hline $\begin{array}{l}\text { Information units } \\
\text { without outliers } n=18\end{array}$ & $\begin{array}{c}\mathrm{rs}=0.52 \\
\mathrm{p}=0.0273\end{array}$ & $\begin{array}{l}\mathrm{rs}=0.65^{*} \\
\mathrm{p}=0.035\end{array}$ & $\begin{array}{l}r s=0.59 \\
p=0.106\end{array}$ & $\begin{array}{l}r s=0.43 \\
p=0.727\end{array}$ & $\begin{array}{c}r s=0.59 \\
p=0.0106\end{array}$ & $\begin{array}{l}r s=-0.26 \\
p=0.3044\end{array}$ \\
\hline
\end{tabular}

* Significant data for AVPs with rs.

(Schoenoplectus californicus) at the same location. For other species of "tiriricas" and "capins" (12 species), cutting was performed at least once a year. Before producing handicrafts, the collected material could usually be stored for up to two years. As measurement units for storage and production, the interviewees mentioned the "feixe" (bundle), with an average diameter of $0.70 \mathrm{~m}$ when dry, and the "boneca" (small bundle), with a diameter of $0.20 \mathrm{~m}$.

Some of the proportions and measures for the main types of handicrafts produced are as follows: For "junco" (Schoenoplectus californicus), 13 green bundles correspond to 10 dry bundles, which enable the production of eight mats measuring $7.5 \mathrm{~m}^{2}$ (60 $\mathrm{m}^{2}$ in total), using $2 \mathrm{~kg}$ of rami (thread for weaving). The mats are produced in three sizes: $5 \mathrm{~m}^{2}, 7.5 \mathrm{~m}^{2}$, and $10 \mathrm{~m}^{2}$. For covering chairs using Typha domingensis and T. latifolia, an average of 60 green bundles are employed, corresponding to 10 dry bundles, which are used for covering 80 to 100 chairs, and each chair takes 3 to 5 hours to be produced. Braids of "taboa" and "tiririca" are combined to make bags that are sold both within and outside of the community.

When the crafts are ready, they are sold or stored until the appearance of a buyer. At some times, the crafts are 
also produced to order. According to the interviewees, the economic gains are not high, but they do complement annual income and are used to purchase materials such as threads and to pay plant cutters and help with family expenses. In addition to economic gains, these activities are considered to be a component of cultural values, a stimulus to live and a way to pass time (reported by older people). Regarding the consumer market, it was noted that over $95 \%$ of people produce handicrafts to order, and $25 \%$ of people use the handicrafts that they make. Only two people reported selling products in the marketplace.

\section{Discussion}

\section{Knowledge of aquatic vascular plants that are used for handicrafts}

The total number of AVPs that were used at the time of the study ( 16 species) represented $3 \%$ of 500 species (Irgang \& Gastal 1996) and $6 \%$ of 250 species (Rolon et al. 2010) that have been reported in the state of Rio Grande do Sul. This result suggests that although a high proportion of AVPs exist in one place, few are selected for handicraft use. The small number of species used may be influenced by reduced support systems of different types of macrophytes (e.g., free-floating, submergent) (Chambers et al. 2008), with emergent plants being the principal type used in these activities.

The number of species used for handicrafts was representative of the number recorded in other studies in the same region (Coelho-de-Souza et al. 2008; Bitencourt 2009). Additionally, this study is the first to report 11 new species with artisanal uses; similar data have not been obtained in any other study regarding vegetal fibers of artisanal relevance.

This result shows that the range of AVPs employed for this purpose is greater than ethnobotanical studies have shown previously. The new species are Androtrichum giganteum, Cyperus eragrostis, C. hermaphroditus, C. odoratus, C. rigens, $C$. surinamensis, Eleocharis montana, Fimbristylis dichotoma, Juncus microcephalus, Kyllinga odorata, and Rhynchospora holoschoenoides.

Furthermore, four of the species registered in this study are also used in other countries: Schoenoplectus californicus is used in Mexico (Elizondo et al. 2008), Ecuador and Peru (Macía \& Balslev 2000; Banack et al. 2004; Vidaurre et al. 2006); Typha domingensis is used in Iran (Parsapajouh \& Ghahremaninejad 2006) and Peru (Heiser 1978); Typha latifolia is used in Italy (Salerno et al. 2005) and Europe (Nedelcheva et al. 2011); and Andropogon bicornis is used in Colombia (Giraldo-Cañas 2010).

The high similarity of the species recorded in this study to those that are used in other countries may be related to the convergence of cultural traits, as populations have the same resources in their environment and experience the use of these resources in the same way, which is influenced by species morphology (Kotze \&Traynor 2011). The four species that were most well known by the interviewees were the most abundant and dominant species (monospecific states) in the aquatic environment (Irgang \& Gastal 1996; Kafer et al. 2011) and in areas with a fluvial influence near the Atlantic forest. Similarly, these species have been reported to be dominant in other studies, and they occupy large areas of New Zealand, Middle Eastern countries, Africa and several countries from Mexico to Argentina (Lange et al. 1998; Elizondo et al. 2008; Pratolongo et al. 2008; Sabaj 2011). These abundance and distribution characteristics of AVPs support the premise that species that are more abundant are the most commonly known and used by local people (Phillips \& Gentry 1993).

\section{Versatility of aquatic vascular plants for handicraft}

Based on the consensus value for the forms of use (CMU), the use forms of mats, braids and fiber for covering chairs were predominant for all 16 species. These forms were mainly produced from four botanical species. This low number of types of artisanal items may be indicative of specialization in artisanal activity in this location.

For the artisanal form referred to as arrangement, the inflorescences of 12 species of AVPs were used, which may suggest that these plant species are associated with low use pressure, as several species were used to produce the same artisanal form, and these species were used by only one person. According to Albuquerque \& Oliveira (2007), greater redundancy (number of plants in the same category of use) decreases the use pressure on species because people can use different resources, thus avoiding overexploitation of a single or a limited number of species. However, for this form of use, the number of areas from which the plants were collected was not evaluated, and neither frequency nor preference data were available for these species, making it impossible to determine whether they experienced pressure related to extraction.

The more versatile species, i.e., those from which the largest number of different types of handicrafts were produced, were Typha domingensis and T. latifolia, followed by Androtrichum giganteum. This versatility may be associated with the part of the plant that is used (leaves) allowing greater versatility (Kotze \& Traynor 2011).

Other species referred to as "tiriricas" and "capins" exhibit dense inflorescences that are typical of the Cyperaceae and Poaceae families (Alves et al. 2009). This common appearance supports the assumption that morphological features of plants may influence the type of handicraft produced and may increase the potential number of products that are made, as proposed by Kotze \& Traynor (2011), whereas the versatility of plants is based on their morphological features and the number of artisanal objects. 
It is important to highlight that Schoenoplectus californicus presented less versatility in use forms (four forms) than other species. This lower versatility is related to the rigidity and shape of its stems, which defines the types of handicraft that are produced (Lange et al. 1998). This species is especially suitable for producing mats, as noted by Kotze and Traynor (2011) for the species Schoenoplectus corymbosus and S. scirpoides. Furthermore, S. californicus was registered as a building material in this study, similar to observations made in Peru (Heiser 1978) and Ecuador (Macía \& Balslev 2000), although for other types of construction.

Thus, S. californicus was the most commonly known species that was used but was less versatile compared with other species cited in this work. The most-used species would be associated with higher sales and a higher preference among buyers, with greater family effort being involved in its preparation and the transfer of knowledge about this activity. This fact may influence the variability of products, confirming that the best-selling product can lead to the disappearance of others that are less frequently bought. As a result, family and local production dynamics and consequent cultural and economic transition processes may be modified or replaced, which was evident mainly for Schoenoplectus californicus.

\section{Social variables related to the knowledge and artisanal use of AVPS}

In this study, the participants' age, time of residence on site and time working with handicrafts were found to be correlated with greater knowledge and use of species of AVPs for handicrafts. In addition, Gavin \& Anderson (2007) reported that in Peru, the longer families had lived in one place, the greater their knowledge and plant extraction activities were. Constant involvement with activities and permanence provides different learning opportunities for the community.

The results reported by Martin (1995) and Gavin \& Anderson (2007) revealed that a higher level of education is related to less knowledge and use of vegetal resources. This pattern was not verified in the current study. This discrepancy can be explained by the data reported for this community; i.e., while young people (mostly men) abandon school in search for informal jobs with remuneration, older people attend education programs for adults, resulting in a balance. Thus, education is suggested as a topic that should be further assessed, including other factors such as whether people currently attend school and the duration of their studies.

The production of handicrafts was shared between men and women, indicating that this activity not associated with gender. Men and women knew and used the plants in the same proportion (but not in IUs), probably due to the small number of species and the handicraft activities in the region (Barber \& Krivoshlykova 2006). However, women were more commonly associated with tissue activities and men with plant harvesting (cutting). The collection of these plants is considered heavy work, requiring physical force, which may suggest a social division of labor, as reported by Toledo et al. (2007; 2009). On the other hand, weaving activity was more commonly associated with women because they presented greater knowledge of the production of crafts for each plant used ( $17 \%$ greater than men).

These data differ from those reported by Kepe (2003) for Africa, Correa et al. (2010) for São Paulo and Torri (2014) for Chile, where women are responsible for both plant collection and handicraft production. In contrast, in a study conducted by Camou-Guerrero et al. (2008) in Mexico, men displayed greater knowledge of plants used for handicrafts. These differences may be attributed to the type of handicraft produced and the complexity of artisanal items, which are historically related to women's manual skills.

The outliers consisted of people with greater knowledge of these plants (greater numbers of known species, species used and handicrafts produced) in the community. These individuals were either included in or excluded from the analysis, as suggested by Araujo et al. (2012), because such outliers may be the result of individual experience (Soldati 2015) or different sources of learning, which were not evaluated.

Artisanal activity using AVPs is characterized by a low production cost, involving the extraction of noncultivated native plants and the local workforce, which provides a source of income and a strategy for economic diversification in rural areas (Barber \& Krivoshlykova 2006). The community performs artisanal activities to complement their family income, as reported by Virapongse et al. (2014) for palm fiber, whose use was maintained by familiar groups in Ecuador. In the region, 24 families benefit from the economic gains resulting from this activity. Handicrafts based on AVPs consistently exhibit the familiar economic characteristic of serving as an alternative source of income and providing social encouragement for old and young people, as previously mentioned in several studies on nontimber forest products (NTFPs) (Kotze \& Traynor 2011; Torres-Avilez et al. 2014; Torri 2014). Thus, this activity could be promoted by governmental organizations to create jobs and prevent the movement of people from rural areas to municipalities, which is responsible for the continuous disappearance of these cultural practices.

\section{Methods for collecting of AVPs and production of handicraft items}

The cutting strategies for AVPs are based on the knowledge that cutters have of areas and species, allowing them to select individuals with morphological features and cutting times that provide the best yields. A similar pattern of location selection was reported by Guadagnin \& Gravato (2013) in a study on the indigenous Kaingang people in Rio Grande do Sul, where the 
extractors are connoisseurs of extraction areas. This finding indicates that participants who perform collection are capable of species recognition, as they maintain direct contact with natural resources. The selection of plant species with higher yields suggests that these methods are an initial part of the management process.

In artisanal production, the use of simple tools for collecting plants (knife) and manual production ("cavalete") has been shown, which is not exclusive to the present study region, as these types of tools are mentioned in several locations on the American, European and African continents, with similar uses and common patterns of the produced handicrafts being observed (Contreras 1982; Barber \& Krivoshlykova 2006). As previously mentioned, such patterns may be explained by migratory processes (from Europe to Brazil) or the convergence of cultural traits.

The "production" of objects with greater sales potential has resulted in a more elaborate type of handicraft. These products are mainly sold on demand in residences, reflecting the lack of points of sale and informality of the activity as well as the low social and economic value of the artisan and handicrafts that still exists in Latin America and underdeveloped countries (Alexiades \& Shanley 2004; Sabaj 2011). Additionally, the introduction of cheaper artisanal products (such as mats, pan holders, and decorative table sets) from the Asian continent, and especially China, has intensely commercialized handicraft shops in the area, decreasing the competition capacity of the local product.

As noted by Contreras (1982), a large portion of the producers (95\%) in Peru only produce artisanal objects encouraged by financial return. This finding suggests that if the market no longer demands these products, artisanal production based on AVPs will decrease or disappear. For example, some interviewees mentioned that the number of families producing mats decreased when local governments stopped buying these products for use in the containment of dunes. Currently, this activity is restricted to the few families included in this research.

This study demonstrated the importance of AVPs for handicrafts in communities of southern Brazil as well as the considerable knowledge related to plants and the artisanal process, from the selection of locations to artisanal production. The wealth of AVPs recorded in this work is representative of the findings of other studies, and such widely known plants reflect the cultural knowledge that is being transmitted and maintained in the region. The registration of the artisanal use of new species expands the range of plants that can be used and the knowledge of morphological features related to their selection, extraction and processing techniques.

Handicrafts are considered a complementary activity for family income for economic diversification. The maintenance and knowledge of cultural practices, such as the production of handicrafts using AVPs, are influenced by several factors, such as a population's social profile and the features of the plants that are used and their associated products, which are constantly driven by the consumer market.

\section{Acknowledgements}

We sincerely thank the communities visited in the municipalities of Imbé, Maquiné, and Osório. We also acknowledge the Laboratory of Ecology and Evolution of Social-Ecological Systems (Federal Rural University of Pernambuco) for their assistance in the data analysis. Additionally, we thank Rumi Kubo and Gabriela Coelho-deSouza. Besides, we thank Jenny Angarita. This paper is the contribution number fifteen supported by CAPES/PNADB through the project "Knowledge, use and conservation of plant biodiversity in Atlantic forest and Caatinga" (UFSC/ UFRPE/UFRGS).

\section{References}

Albuquerque UP, Oliveira RF. 2007. Is the use-impact on native caatinga species in Brazil reduced by the high species richness of medicinal plants? Journal of Ethnopharmacology 113: 156-170.

Albuquerque UP, Ramos M, Lucena R, Alencar N. 2014. Methods and techniques used to collect ethnobiological data. In: Albuquerque UP, Cunha LVFC, Lucena RFP, Alves RRN. (eds.) Methods and techniques in ethnobiology and ethnoecology. New York, Springer. p. 9-64.

Alexiades M, Shanley P. 2004. Forest products, livelihoods and conservation: case studies of Non-Timber forest product systems. In: Alexiades MN, Shanley P. (eds.) Forest products, livelihoods and conservation case studies of non-timber forest product systems. Vol. 3 - Latin America. Bogor Barat, CIFOR. p. 3.

Alves M, Araújo A, Prata A, et al. 2009. Diversity of Cyperaceae in Brazil. Rodriguésia 60: 771-782.

Alves M, Hefler S, Trevisan R, Silva Filho P, Ribeiro A. 2015. Cyperaceae in lista de espécies da flora do Brasil. Jardim Botânico do Rio de Janeiro. http://reflora.jbrj.gov.br/reflora/listaBrasil/PrincipalUC/PrincipalUC. do\#CondicaoTaxonCP. 30 Mar. 2017.

Araújo TA, Almeida AL, Melo JG, et al. 2012. A new technique for testing distribution of knowledge and to estimate sampling sufficiency in ethnobiology studies. Journal of Ethnobiology and Ethnomedicine 8: 11.

Arruda RS. 1999. Populações tradicionais e a proteção dos recursos naturais. Ambiente e Sociedade 2: 79-93.

Bailey K. 1994. Methods of social research. 4th. edn. New York, The Free Press.

Banack S, Rondón XJ, Diaz-Huamanchumo W. 2004. Indigenous cultivation and conservation of totora (Schoenoplectus californicus, Cyperaceae) in Peru. Economic Botany 58: 11-20.

Barber T, Krivoshlykova M. 2006. Global market assessment for handicrafts. Washington, United States Agency for International Development.

Bitencourt L. 2009. O artesanato de "taboa" (Typha cf. dominguensis Pers.) e junco (Androtrichum trigynum (Spreng.) H. Pfeiff.) na Guarda do Embaú, Palhoça, SC. MSc Thesis, Universidade Federal de Santa Catarina, Florianópolis.

Brasil. 2012. Lei n ${ }^{\circ}$ 12.651, de 25 de maio de 2012. Brasília, DOU, Seção 1 - 28/5/2012, p. 1.

Byg A, Balslev H. 2001. Diversity and use of palms in Zahamena, eastern Madagascar. Biodiversity and Conservation 10: 951-970.

Camou-Guerrero A, Reyes-García V, Martínez-Ramos M, Casas A. 2008. Knowledge and use value of plant species in a Rarámuri community: a gender perspective for conservation. Human Ecology 36: 259-272. Chambers PA, Lacoul P, Murphy KJ, Thomaz SM. 2008. Global diversity of aquatic macrophytes in freshwater. Hydrobiologia 595: 9-26.

Coelho-de-Souza G, Kubo R, Andrade-Miguel L. 2008.Extrativismo da 
samambaia-preta no Rio Grande do Sul. Porto Alegre, Editora da UFRGS. p. 17-37.

Contreras J. 1982. La producción artesanal en los Andes Peruanos: del valor de uso al valor de cambio. Boletín Americanista 32: 101-114.

Correa D, Ming L, Pinedo-Vasques M. 2010. Manejo de Fibras Vegetais utilizadas em artesanatos por comunidades tradicionais do parque Estadual e Turístico do Alto Ribeira e seu entorno, Iporonga, SP. In: Silva V, Almeida AS, Albuquerque U. (eds.) Etnobiologia e etnoecologia, pessoas e natureza na América Latina. Recife, Nuppea. p. 175-207.

Cunningham AB. 2001. Etnobotánica aplicada: pueblos, uso de plantas silvestres y conservación. Vol. I Pueblos e Plantas. Manual de Conservación. Nordan. WWF-UK.

Dogan Y, Nedelcheva A, Obratov-Petkovic D, Padure I. 2008. Plants used in traditional handicrafts in several Balkan countries. Indian Journal of Traditional Knowledge 7: 157-161.

Elizondo MSG, Elizondo MG, Flores JAT, Enriquez ILL, Reznicek AA, Diego-Pérez N. 2008. Sinopsis de Scirpus sl (Cyperaceae) para México. Acta Botánica Mexicana 82: 15-41.

FGTAS - Fundação Gaúcha do Trabalho e Ação Social. 2016. Programa gaúcho do artesanato: relatório: 2016. Porto Alegre. http://www.fgtas. rs.gov.br/programa-gaucho-do-artesanato. 15 Mar. 2017.

Gavin MC, Anderson GJ. 2007. Socioeconomic predictors of forest use values in the Peruvian Amazon: a potential tool for biodiversity conservation. Ecological Economics 60: 752-762.

Giraldo-Cañas D. 2010. Gramíneas (Poaceae) ornamentales y usadas en artesanías en Colombia. Polibotánica 30: 163-191.

Guadagnin DL, Gravato IC. 2013. Ethnobotany, availability and use of lianas by the Kaingang people in Suburban Forests in Southern Brazil. Economic Botany 67: 350-362.

Heiser C. 1978. The totora (Scirpus californicus) in Ecuador and Peru. Economic Botany 32: 222-236.

IBGE - Instituto Brasileiro de Geografia e Estatística. 2016. Rio Grande do Sul. http://cidades.ibge.gov.br/xtras/perfil.php?codmun=431350. 30 Jul. 2017.

Irgang B, Gastal JCV. 1996. Macrófitas aquáticas da planície costeira do Rio Grande do Sul. Porto Alegre, UFRGS.

Jain A, Roshnibala S, Rajshree K, Nandiram SH, Kanjilal P, Birkumar SH. 2005. Matting rush (Schoenoplectus lacustris (Linn.) Palla): status, utility, threat, cultivation and conservation options in Manipur. Current Science 89: 1018-1022.

Junk WJ, Piedade MTF, Lourival R, et al. 2014. Brazilian wetlands: their definition, delineation, and classification for research, sustainable management, and protection. Aquatic Conservation: Marine and Freshwater Ecosystems 24: 5-22.

Kafer DDS, Colares IG, Hefler SM. 2011. Composição florística e fitossociologia de macrófitas aquáticas em um banhado continental em Rio Grande, RS, Brasil. Rodriguésia 62: 835-846.

Kepe T. 2003. Use, control and value of craft material Cyperus textilis: perspectives from a Mpondo village, South Africa. South African Geographical Journal 85: 152-157.

Kotze DC, Traynor CH. 2011. Wetland plant species used for craft production in KwaZulu-Natal, South Africa: ethnobotanical knowledge and environmental sustainability. Economic Botany 65: 271-282.

Lange PJ, Gardner RO, Champion PD, Tanner CC. 1998. Schoenoplectus californicus (Cyperaceae) in New Zealand. New Zealand Journal of Botany 36: 319-327.

Macía MJ, Balslev H. 2000. Use and management of totora (Schoenoplectus californicus, Cyperaceae) in Ecuador. Economic Botany 54: 82-89.

Marcus T. 2000. Crafting in the context of AIDS and rural poverty: a livelihood strategy with prospects. Transformation 44: 17-35.

Martin G. 1995. Etnobotánica: Manual de métodos. Pueblos y Plantas. Fondo mundial para la naturaleza. Montevideo, Nordan Comunidad.

Monteiro JM, Albuquerque UP, Lins-Neto EM, Araújo EL, Amorim EL. 2006. Use patterns and knowledge of medicinal species among two rural communities in Brazil's semi-arid northeastern region. Journal of Ethnopharmacology 105: 173-186.

Nedelcheva A, Dogan Y, Obratov-Petkovic D, Padure IM. 2011. The traditional use of plants for handicrafts in southeastern Europe. Human Ecology 39: 813-828.
Parsapajouh S, Ghahremaninejad F. 2006. Ethnobotanical use of Typha domingensis pers. (Typhaceae) in an arid zone: Sistan, Iran. Zonas Áridas 8: 7-17.

Phillips O, Gentry AH. 1993. The useful plants of Tambopata, Peru: I. Statistical hypotheses tests with a new quantitative technique. Economic Botany 47: 15-32.

Pratolongo P, Kandus P, Brinson M. 2008. Net above ground primary production and biomass dynamics of Schoenoplectus californicus (Cyperaceae) marshes growing under different hydrological conditions. Darwiniana 46: 258-269.

Rienzo JA, Casanoves F, Balzarini MG, Gonzalez L, Tablada M, Robledo CW. 2017. InfoStat, versión 2017. Córdoba, Grupo InfoStat, FCA, Universidad Nacional de Córdoba. http://www.infostat.com.ar/.10 Mar. 2017.

Rolon A, Homem H, Maltchik L. 2010. Aquatic macrophytes in natural and managed wetlands of Rio Grande do Sul State, Southern Brazil. Acta Limnologica Brasiliensia 22: 133-146.

Rondón XJ, Banack SA, Diaz-Huamanchumo W. 2003. Ethnobotanical investigation of caballitos (Schoenoplectus californicus: Cyperaceae) in Huanchaco, Peru. Economic Botany 57: 35-47.

Sabaj V. 2011. Extracción do junco Schoenoplectus californicus em el area protegida humedal del Santa Lucia (Uruguai) contexto ecologico, sociespacial y perpectivas de manejo sustentável. MSc Thesis, Montevideo Universidad de la República, Montevideo.

Salerno G, Guarrera PM, Caneva G. 2005. Agricultural, domestic and handicraft folk uses of plants in the Tyrrhenian sector of Basilicata (Italy). Journal of Ethnobiology and Ethnomedicine 1: 2.

Santoro FR, Ferreira Júnior WS, Araújo TA, Ladio AH, Albuquerque UP. 2015. Does plant species richness guarantee the resilience of local medical systems? A perspective from utilitarian redundancy. PLoS One 10: e0119826. doi: 10.1371/journal.pone.0119826.

Silveira TCL, Bassi J, Ramos C, et al. 2011a. Schoenoplectus californicus Junco. In: Coradin L, Siminski A, Reis A. (eds.) Espécies nativas da flora brasileira de valor econômico atual ou potencial: Plantas para o Futuro - Região Sul. Brasília, Ministério do Meio Ambiente. p. 282-290.

Silveira TCL, Coelho-de-Souza GC, Rodrigues GG. 2007. Crescimento Produção primária e regeneração de Typha domingensis Pers: Elementos para avaliação do uso sustentável da espécie. Revista Brasileira de Biociências 5: 678-680.

Silveira TCL, Rodrigues GG, Coelho-de-Souza GC, Würdig N. 2011b. Effects of cutting disturbance in Schoenoplectus californicus (C.A. Mey.) Soják on the benthic macroinvertebrates. Acta Scientiarum. Biological Sciences 33: 31-39.

Soldati GT. 2015. Knowledge transmission: the social origin of information and cultural evolution. In: Albuquerque UP, Medeiros PM, Casas A. (eds.) Evolutionary ethnobiology. Cham, Springer International Publishing. p. 89-104.

Stevens PF. 2016. Angiosperm Phylogeny Website. St Louis http://www. mobot.org/MOBOT/research/APweb. 15 Mar. 2017.

Sunderland T, Ndoye O. 2004. Forest products, livelihoods and conservation: case studies of non-timber forest product systems. Vol. 2 - Africa. Jakarta, Center for International Forestry Research (CIFOR). p. 333.

Toledo B, Colantonio S, Galetto L. 2007. Knowledge and use of edible and medicinal plants in two populations from the Chaco forest, Córdoba Province, Argentina. Journal of Ethnobiology 27: 218-232.

Toledo B, Galetto L, Colantonio S. 2009. Ethnobotanical knowledge in rural communities of Cordoba (Argentina): the importance of cultural and biogeographical factors. Journal of Ethnobiology and Ethnomedicine 5: 1-8.

Torres-Avilez W, Nascimiento L, Campos L, Silva F, Albuquerque U. 2014. Gênero e idade. In: Albuquerque U. (ed.) Introdução à etnobiologia. Recife, Nuppea. p. 63-174.

Torri MC. 2014. Linking local plants with small handicraft enterprises among indigenous Mapuche communities: towards a combined approach of local development and enhancement of ethnobotanical knowledge? Bulletin of Latin American Research 33: 419-435.

Vidaurre J, Paniaguan N, Moraes M. 2006. Etnobotanica en los Andes de Bolivia. Botánica Económica en los Andes Centrales 1: 224-238.

Virapongse A, Schmink M, Larkin S. 2014. Value chain dynamics of an emerging palm fiber handicraft market in Maranhão, Brazil. Forests, Trees and Livelihoods 23: 36-53. 